E

98

F6B87 I

1921

NMAI

INDIAN FOLK LORE

CHARLES E. BROWH 



\section{INDIAN FOLK LORE}

Prepared for the use of Students of the tion 255269

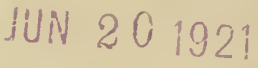

Prepared for the use of Students of the tional Musey

\section{UNIVERSIT Y OF WISCONSIN \\ SUMMER SESSION}

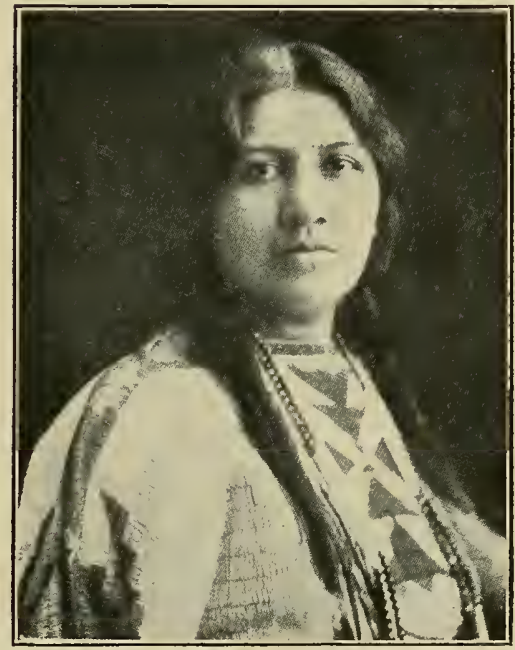

ANGEL, DECORA

Wisconsin Winnebago

CHARLES E. BROWN

Chief, State Historical Museum

MADISON, WISCONSIN 



\section{INDIAN MYTHS}

\section{THE CREATION OF THE WORLD}

Wisûkejak was traveling when he heard a noise behind him and turned to find the waters rising. He fled and climbed into a tall tree. The water rose higher and higher until it reached his neck. Then he saw a beaver and a muskrat. He called to them and they came. He begged them to dive down into the waters and bring him a little mud. First the beaver tried and failed. Then the muskrat went down into the water. After several trials he brought up a little sand in one paw and with this Wisûkejak formed the earth. (Cree.)

The earth is a great island floating in a sea of water and suspended at each of the four cardinal points by a cord hanging down from the sky vault, which is of solid rock. When the world grows old and worn out, the people will die and the cords will break and let the earth sink down into the ocean, and all will be water again. The Indians are afraid of this. (Cherokee.)

Everything was water except a small piece of ground. On this were the Eagle and Coyote. Then the Turtle swam to them. He was sent to dive for earth at the bottom of the water. He barely succeeded in reaching the bottom and touched it with his foot. When he came up Coyote examined his nails and found a grain of earth.

He and Eagle took this and made the earth as large as it is. From it they also made six men and women. They were sent out in pairs in different directions. After a time Eagle sent Coyote out to see what they were doing. He found them eating the earth. The Eagle said: "That is bad. Let us make something for them to eat." They sent the Dove out to find something. It found a single grain of meal. They put this in the ground and the earth became filled with seeds and fruit. They told the people to eat these. When they were ripe the people gathered them. Then the people increased and spread. But water is still under the world. (Yoliuts.)

\section{MAN}

Having made the earth, Earthmaker decided to make a man. He built a little oven of stones. Then moulding with his hands a little figure of clay, he put it in the oven to bake. Soon he took it out. It was not baked enough; it came out white. That was the white man. 
He tried again but this time he left the figure in the oven too long. It was burnt and came out black. That was the negro. He tried again and watched the fire carefully, and behold he had a perfect man, an Indian, "baked just right." (Cree.)

Falcon proposed to Coyote that he show his power by creating human beings. Coyote said that it would mean a great deal of work, but he would try.

Coyote threw himself on the ground and pretended to be dead. Soon a large number of crows and buzzards gathered about him and began to eat his flesh. Coyote, rising suddenly, caught a number of them. Falcon plucked out their feathers, and on each hill placed some of them. Coyote named the places where they were put. The crow feathers became common people and the buzzard feathers, chiefs. (Miuok.)

\section{THE ANIMALS}

An Eskimo was chopping down a tree. He noticed that the chips which fell into the water became water animals and those that fell on the land became land animals. Before this time the earth had been covered with water. The water went away and dry land appeared. The seaweed and kelp became trees and grass. (Eskimo.)

\section{THE SUN AND MOON}

A brother and his sister quarrelled. She would not make up. He chased her 'round and 'round the house. Then she ran up into the sky and lie after lier. They became the sun and the moon. The sun is constantly following the moon. Sometimes they meet (when there is an eclipse). (Eslimo.)

The Sull was a young woman and lived in the East; her brother, the Moon, lived in the West. The girl had a lover who came every month in the dark of the moon to court her. She could not see his face in the dark and he would leave before daylight. He would not tell her his name. She wondered who he was. At last she hit on a plan to find out. So the next time she came, when they were sitting together she slyly dipped her hand into the ashes of the fireplace and rubbed it over his face, saying "Your face is cold, you must have suffered from the wind. She pretended to be very sorry for him. After a while lie went away.

The next night when the Moon came up in the sky she saw that his face was covered with spots, and knew that he had been the one who had been coming to court her. He was so ashamed that he kept as far away as he could at the other end of the sky all the night. Ever since he tries to keep a 
long way behind the Sun. When he sometimes comes too near her in the West he makes himself as thin as a ribbon so that he can hardly be seen. (cherokee.)

\section{THE WINDS AND RAIN}

There is a giant spirit who lives in the North. When he blows his breath, violent snowstorms occur. Other spirits live in the East and West. They breathe soft winds and summer rain. They live up in the sky and keep the rain in bags. When they run across the sky the water escapes. The thunder is the noise of their running. (Eskimo.)

Gluskap was staying at Chief Raven's village. For many days none of the Indians had done any hunting or fishing, for it was so windy that no one could get near any game, nor did any one dare to launch a canoe. Gluskap knew why it was windy, for Wind Bird was flapping his wings harder than usual. He advised the chief to send some of his men up the mountain, where Wind Bird lived, to tie his wings. It was so windy that they climbed the mountain with difficulty. Wind Bird was making so much noise that he did not notice them. One of the men knocked him down with a stone. Then they tied him fast with cedar bark ropes.

For a while everything was delightful. There was no wind at all. They caught many fish and killed much game. After a time all the waters becane stagnant. It was very warm, too, for there was no cooling breeze. The chief consulted Gluskap, who told him to send the men back to untie one of Wind Bird's wings. Since then everything has gone well. Only occasionally there is a high wind. That is when the Wind Bird is trying to escape. (Malecite.)

\section{THE THUNDER BIRDS}

These great birds have their nests on the top of the highest mountains. When the weather is stormy they fly about high up in the air. When they flap their great wings you hear the crashes of thunder. When they open-and-close their eyes the lightning flashes are seen. When their wings strike the clouds it rains. When they are angry they drop their eggs on the villages and then people are killed. They set fire to the forests and shatter the rocks. They carry away people, who are never heard of again.

The old birds sometimes say to the young ones, "Be careful or you will scare the Indians. You will fly very easy over their camps and villages." If the birds know that anyone is afraid of them, they are the ones they go after. They are 
burned or killed. If you watch for them when it storms you may see or hear the Thunderers. (Chippewu.)

\section{THE RAINBOW}

Sais-ta-go-wa, the Rainbow, was a sea monster. Hah-gwehda-et-gah, the Bad Minded, brought him forth to destroy the beautiful rivers and hills, which Hah-gweh-di-yu, the Good Minded, had created. He began his work of destruction. When Hah-gweh-di-yu hastened to the rescue he fled to the sky. Here the Sun found him and throwing him across the sky, clasped him down to the east and the west, so he could do no further injury.

He-no, the Thunder, passing on his way through a storm admiring his beautiful colors as he stretched across the sky, picked him up, saying: "My Lightning Hunter needs this for his bow," and carried him to his lodge.

Sais-ta-go-wa is restless in his captivity, and when He-no is busy directing his storms, endeavors to escape. The everwatchful Sun detects him and again bending him across the sky, paints him with its brightest colors, that he may be discovered by He-no, who quickly comes and carries him back to his lodge. (Iroquois.)

\section{THE SEVEN STARS (The Pleiades)}

Seven boys were playing and dancing together in the shade of a large tree. After a while they became hungry. One went to a wigwam and asked an old woman for food. She would give him none and told him to go on dancing. They danced again, then another boy went to the house. She still refused to give them anything to eat.

They danced again around the tree. One made a drum. They began to be lifted upwards, their feet leaving the ground. They kept on dancing and still higher they ascended. The old woman went to the tree with food. She saw them dancing high above the tree. She called to them to come and eat. Too late, they would not listen to her. She called again and again, but they did not hear her. They kept on dancing, still moving upwards. The old woman wept. The seven stars which we now see in a cluster high in the heavens, are the dancing boys. (Huron and Wyandotte.)

\section{STARS}

There are different opinions about stars. Some people say they are balls of light, other's say they are human, but most people say they are living creatures covered with luminous fur or feathers. 
Some hunters once found two of them. They were strange creatures with round bodies covered with fine fur or downy feathers,from which small heads stuck out.

The hunters took them home. Every night they would grow bright and shine like great stars. In the daytime they were only balls of grey fur. One night they suddenly rose from the ground, like balls of fire, and were soon above the tree tops. Higher and higher they went while the wondering hunters watched, until at last they were only two bright points of light in the dark sky, and then the hunters knew that they were stars. (Cherokee.)

Two stars, large and bright, married two Indian girls. The girls were very unhappy, however, since they only saw their husbands at night and never in the day time. (Crec.)

\section{THE MILKY WAY}

Some people had a corn mill, in which they pounded corn into meal. On several mornings when they came to fill it they noticed that some of the meal had been stolen during the night. They examined the ground and found the tracks of a dog. The next night they watched and when the dog came from the North and began to eat the meal they sprang out and beat him. He ran off howling, with the meal dropping from his mouth as he ran, and leaving behind a white trail where we now see the Milky Way, which the Indians call by a name meaning "Where the dog ran." (Cherokee.)

The Milky Way is the "bird's path." The fowl and birds follow it southward in the autumn and back again in the spring. It is also the "spirit path" along which the spirits of the dead journey. (Timiskaming.)

\section{THE AURORA BOREALIS}

In the direction of the North Wind live the Manabaî wok (giants) of whom the old people tell. They are our friends but we do not see them any more. They are great hunters and fishermen and whenever they are out with their torches to spear fish we know it, because the sky is then bright over the place where they are. (Henomini.)

\section{INDIAN SUMMER}

When the late summer Sun "walks crooked" he is on his way to the south sky, where during the winter he rests, leaving his "sleep spirit" on guard in his absence.

Before his departure he smokes the peace pipe to veil the earth (autumn mists) as he councils with the great mother. (Iroquois.) 


\section{THE OBTAINING OF FIRE}

The hill people had no fire. Only to the West, on the plains, was there a man who had fire, and he had it all.

When he slept, the antelope, selected for its swiftness, was sent to steal his fire. It took a fire brand and fled. Before it could get back to the people rain fell and put it out. Other animals tried to get fire but failed. At last the jackrabbit tried. After he had stolen it he hid it in a thick bush. Then he crouched over it to shield it from the rain. From this the palms of his hands are black. So he obtained fire for the Indians. (Yokuts.)

\section{CORN}

Among the birds which came from the sun land, Ga-gaah, the crow, carried a kernel of corn. Ha-gweh-di-yu planted his mother (the earth) and it became the first grain, the life of the redman. By this birthright, Ga-gaah, claiming his share, hovers above the fields, guarding the young roots from the foes that infest them. (Iroquois.)

Two Indians had killed a deer and were roasting a part of it to eat. A beautiful woman was seen to descend from the clouds and alight upon the earth. They concluded that she must be hungry and had smelled the meat. They invited her to eat. When she left she told them to return, in one year, to the spot where she had been sitting and they would find there a return for their kindness and generosity.

The two men returned to the village and told the Indians what they had seen and done-but they were laughed at by their people.

When the time arrived they went to the spot where they had seen the sky woman. They found where her right hand had rested on the ground, corn growing-and where the left hand had been, bcuns, and where she had been seated, tobucco. (suc.)

\section{TOBACCO}

Ma nabush was passing a mountain when he detected a delightful odor issuing from a crevice. He found the mountain to be the home of a giant, who was the keeper of tobacco. He crept into a cavern and found the giant. He asked Ma nabush what he wanted. He asked for tobacco, but the giant refused. Ma nabush saw a large number of bags filled with tobacco. He snatched one and ran out of the cavern pursued by the giant.

Ma nabush climbed to the mountain tops, leaping from peak to peak, the giant following. On the edge of a high cliff Ma na- 
bush suddenly threw himself flat on the rocks. The giant leaped over him and down into the chasm beyond. He was much bruised but he managed to climb up the face of the cliff and almost reached the top. There he clung. Ma nabush grasped him by the shoulders, and, drawing him upward, threw him violently to the ground saying: "For your meanness you shall become Kakú ene ('the jumper'-grasshopper). and you shall be known by your stained mouth. You shall become the pest of those who raise tobacco."

He divided the tobacco among his brothers and younger brothers giving to each some of the seed, that they might never be without it for their use and enjoyment. (Menomini.)

\section{MAPLE SUGAR}

A woman was collecting maple sap. She found a lump of maple sugar in the wooden trough which she had placed beneath the spile driven into the tree to convey the running sap. The tree spirit told her not to eat it. She was told to keep it as a charm, and use it when making sugar.

By making a mark in the big kettle with the lump the boiling sap would always fill it to that spot. It brought her good fortune. (Huron.)

\section{THE COMING OF THE WHITE MAN}

When the white man first was seen here, in the old time, he began to barter with our ancestors. Nowhere could he step without coming across a redman (all the land being occupied). The stranger came with a cow's hide, saying that he wanted a piece of land. The Indian thinking that he wanted a piece of land of that size agreed to trade.

The white man, however, cut the hide into a long string and measured off a large piece. The Indian said: "This is the way the white man does. He cheats the Indian." And he had to give away the land measured by the string. (Huron.)

\section{ETERNAL LIFE}

Once Nänibozhu was at home and beating a water drum. Four men heard it, and travelled toward the sound. They walked for eight days but the drummer seemed to be as far away as ever. All at once they came upon him. Nänibozhu gave them various medicines. He said: "That's why I was drumming, to call you." He promised to give them anything they should wish for. Three of the men asked to live until their hair was white. The fourth begged for eternal life. Nänibozhu turned him into a stone. (Chippewa.) 

- 



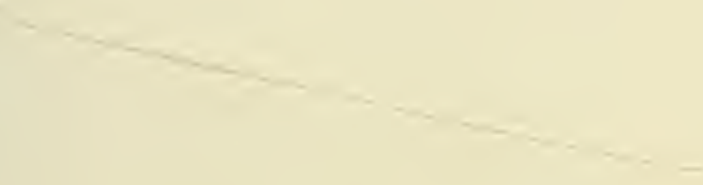

• 
SMITHSONIAN IÑSTITUTION LIBRARIEŠ

E

$\begin{array}{llll}3 & 9088 & 00637 & 1249\end{array}$

98

F6B87 I

1921

NMAI

INDIAN FOLK LORE

CHARLES E. BROWH 